\title{
The Biotransformation of Two 3,15-Oxygenate ent-Kaurane Derivatives by Gibberella fujikuroi
}

\author{
Braulio M. Fraga, ${ }^{*}{ }^{\dagger}$ Melchor G. Hernández, ${ }^{\dagger}$ and Ricardo Guillermo ${ }^{\ddagger}$ \\ Instituto de Productos Naturales y Agrobiología, P.O. Box 195, 38206-La Laguna, Tenerife, Canary Islands, Spain, and \\ Departamento de Quimica Orgánica, Universidad de La Laguna, Tenerife, Canary Islands, Spain
}

Received April 22, $1996^{\star}$

\begin{abstract}
The incubation of $3 \alpha, 15 \beta$-dihydroxy-ent-kaur-16-ene (1) with the fungus Gibberella fujikuroi gave $3 \alpha, 7 \alpha, 15 \beta$-trihydroxy-ent-kaur-16-ene (5), $3 \alpha, 11 \beta, 15 \beta$-trihydroxy-ent-kaur-16-ene (13), and $3 \alpha, 7 \alpha, 11 \beta, 15 \beta$-tetrahydroxy-ent-kaur-16-ene (17). The ether $3 \alpha, 15 \beta$-dihydroxy-11 $\beta, 16 \beta$-epoxyent-kaurane (15) and the isomerized compounds $3 \alpha, 7 \alpha$-dihydroxy-15-oxo-ent-(16S)-kaurane (8) and $3 \alpha, 7 \alpha, 11 \beta$-trihydroxy-15-oxo-ent-(16S)-kaurane (10) were also obtained. The incubation of $3 \alpha$-hydroxy-15-oxo-ent-(16S)-kaurane (7) with the fungus also afforded compounds 8 and 10, as well as $3 \alpha, 11 \beta$-dihydroxy-15-oxo-ent-(16S)-kaurane $(20), 3 \alpha, 6 \alpha, 11 \beta$-trihydroxy-15-oxoent-(16S)-kaurane, (22) $3 \alpha, 6 \beta, 7 \alpha$-trihydroxy-15-oxo-ent-(16S)-kaurane (25), and $3 \alpha, 11 \beta, 16 \alpha-$ trihydroxy-15-0xo-ent-(16S)-kaurane (27). These results indicate that in 3,15 -oxygenated entkaurane derivatives the presence of a $3 \alpha$-hydroxyl inhibits oxidation at C-19, while a $15 \beta$ hydroxyl or a 15-oxo group directs hydroxylation at $\mathrm{C}-11(\beta)$ and $\mathrm{C}-7(\alpha)$.
\end{abstract}

The microbiological transformation of ent-kaurene derivatives by the fungus Gibberella fujikuroi (Hypocreaceae) has been the subject of our studies in recent years. We have shown that in diterpenoids of this type, a $15 \alpha$-hydroxyl group induces hydroxylation at $\mathrm{C}-11(\beta)$ and partially inhibits oxidation at C-19,1,2 which is characteristic of the biosynthesis of gibberellins and kaurenolides. ${ }^{3}$ On the other hand, the biotransformation of 15 $\beta, 19$-dihydroxy-ent-kaur-16-ene by this fungus led to the 19 -acid ${ }^{4}$ and then to $15 \beta$-hydroxygibberellins, ${ }^{5.6}$ indicating that a $15 \beta$-hydroxyl group does not inhibit the C-19 oxidation. In another study we have shown that $8 \alpha$-hydroxy-ent-kaur-16-ene (4) is not metabolized by $G$. fujikuroi, because the $3 \alpha-\mathrm{OH}$ group inhibits oxidation at C-19.?

The aim of the present work was to study the biotransformation by $G$. fujikuroi of substrate 1 , which possesses two hydroxyl groups, one at $\mathrm{C}-3(\alpha)$ and the other at $\mathrm{C}-15(\beta)$. The presence of the first group was expected to prevent oxidation at $\mathrm{C}-19$ and the second to increase the overall polarity of the substrate being biotransformed. It was also thought to be of interest to see whether the $15 \beta-\mathrm{OH}$ induced oxidation at C-11. $(\beta)$, as in the case of a $15 \alpha-\mathrm{OH}$ group ${ }^{1,2}$ As a consequence of the results of the feeding of 1 , the incubation of 15-oxo-ent-(16S)-kaurane (7), which is a rearranged product of 1 , was also carried out and is described herein

\section{Results and Discussion}

The initial substrate, $3 \alpha, 15 \beta$-dihydroxy-ent-kaur-16ene (1), was isolated for the first time from the Japanese liverwort Jungermannia vulcanicola, ${ }^{8}$ and now we have obtained it by hydrolysis of the 15-angelate 2, which occurs in Elaseolinum tenuifolium. ${ }^{9,10}$

The incubation with the fungus was carried out in the presence of AMO 1618, a compound that inhibits

\footnotetext{
* To whom correspondence should be addressed. Phone: 34-22 251728. Fax: 34-22-260135.

'Instituto de Productos Naturales.

¥ Departamento de Química Orgánica.

* Abstract published in Advance AC'S Abstracts, September 15, 1996.
}

Table 1. ${ }^{13}$ C-NMR Data for Compounds $1,5,6,14,17$, and 19

\begin{tabular}{crrrrrr}
\hline carbon & \multicolumn{1}{c}{$\mathbf{1}^{\mathbf{a}}$} & \multicolumn{1}{c}{$\mathbf{5}$} & $\mathbf{6}$ & $\mathbf{1 4}$ & $\mathbf{1 7}^{b}$ & \multicolumn{1}{c}{$\mathbf{1 9}$} \\
\hline 1 & 38.8 & 38.4 & 38.1 & 37.9 & 39.4 & 37.6 \\
2 & 27.5 & 27.3 & 23.5 & 23.4 & 27.9 & 23.3 \\
3 & 79.0 & 78.7 & 80.4 & 80.4 & 79.3 & 80.0 \\
4 & 38.8 & 38.6 & 37.6 & 37.8 & 38.5 & 37.9 \\
5 & 54.6 & 51.4 & 51.4 & 54.5 & 53.1 & 51.0 \\
6 & 19.7 & 27.3 & 24.8 & 19.1 & 28.5 & 24.6 \\
7 & 36.5 & 72.2 & 74.2 & 36.1 & 73.2 & 73.5 \\
8 & 45.7 & 50.8 & 49.4 & 49.2 & 51.6 & 48.1 \\
9 & 46.5 & 45.4 & 46.9 & 53.7 & 55.9 & 53.0 \\
10 & 38.9 & 38.8 & 38.7 & 37.8 & 39.8 & 37.9 \\
11 & 18.2 & 18.2 & 17.8 & 67.9 & 66.6 & 67.6 \\
12 & 33.3 & 33.6 & 33.5 & 39.9 & 43.3 & 39.9 \\
13 & 40.2 & 39.8 & 39.9 & 38.3 & 40.5 & 38.1 \\
14 & 38.9 & 29.2 & 28.9 & 38.8 & 29.7 & 28.6 \\
15 & 82.4 & 75.6 & 75.2 & 81.5 & 76.7 & 75.2 \\
16 & 158.6 & 157.9 & 152.7 & 151.5 & 158.8 & 150.7 \\
17 & 104.8 & 105.3 & 106.8 & 106.8 & 107.0 & 107.3 \\
18 & 28.4 & 28.3 & 28.1 & 28.2 & 28.9 & 28.1 \\
19 & 15.5 & 15.5 & 16.7 & 16.6 & 16.3 & 16.7 \\
20 & 16.7 & 17.7 & 18.0 & 17.4 & 18.1 & 17.6 \\
\hline
\end{tabular}

${ }^{\alpha}$ Taken from Grande et al. ${ }^{10 b}$ Solvent: $\mathrm{CD}_{3} \mathrm{OD}$.

the formation of ent-kaur-16-ene without disturbing the post-kaurene metabolism. ${ }^{11,12}$ This facilitates the isolation of the metabolites formed. Chromatography of the neutral fraction gave $5,8,10$, and 17 , and a mixture of other substances.

Compound 5 had a molecular formula $\mathrm{C}_{20} \mathrm{H}_{32} \mathrm{O}_{3}$, as determined by HRMS. Its ${ }^{1} \mathrm{H}-\mathrm{NMR}$ spectrum was very similar to that of substrate 1 , but with a geminal proton to a new hydroxyl group now appearing as a double doublet at $\delta 3.57$. Their coupling constants $(J=11.6$, $4.5 \mathrm{~Hz}$ ) indicated that the alcoholic group must be equatorial and situated at C-1 or C-7. Considering the ${ }^{13} \mathrm{C}-\mathrm{NMR}$ spectrum of 5 (Table 1 ), which was assigned by comparison with that of 1 , the $C-7(\alpha)$ position was chosen for this new alcohol group. Therefore, the structure of $3 \alpha, 7 \alpha, 15 \beta$-trihydroxy ent-kaur-16ene (5) was assigned to this compound.

The MS of the least polar metabolite (8) was in accordance with the formula $\mathrm{C}_{20} \mathrm{H}_{32} \mathrm{O}_{3}$, isomeric with compound 5 . Its ${ }^{1} \mathrm{H}-\mathrm{NMR}$ spectrum showed that the exocyclic double bond and the $15 \beta-\mathrm{OH}$ group of the 
Table 2. ${ }^{13} \mathrm{C}$-NMR Data for Compounds $7-9,11,12$, and 23

\begin{tabular}{ccccccc}
\hline carbon & $\mathbf{7}$ & $\mathbf{8}$ & $\mathbf{9}$ & $\mathbf{1 1}$ & $\mathbf{1 2}$ & $\mathbf{2 3}$ \\
\hline 1 & 37.7 & 37.4 & 37.0 & 36.8 & 36.9 & 39.2 \\
2 & 26.8 & 26.9 & 23.1 & 23.1 & 23.0 & 23.4 \\
3 & 78.5 & 78.5 & 80.3 & 80.1 & 79.7 & 80.3 \\
4 & 38.7 & 38.7 & 37.6 & $37.7^{a}$ & $37.7^{a}$ & 37.7 \\
5 & 54.1 & $51.7^{a}$ & $51.5^{a}$ & 51.3 & 51.0 & 54.8 \\
6 & $18.4^{a}$ & $28.3^{b}$ & 24.4 & 24.2 & 24.1 & 66.9 \\
7 & 37.2 & 71.6 & 74.0 & 74.1 & 73.8 & 42.8 \\
8 & 52.3 & 58.2 & 56.0 & 54.5 & 54.6 & 48.8 \\
9 & 52.2 & $51.5^{a}$ & $51.4^{a}$ & 62.5 & 58.1 & 63.7 \\
10 & 39.2 & 38.9 & 38.9 & $37.6^{a}$ & $37.8^{a}$ & 37.0 \\
11 & $17.9^{a}$ & 17.9 & 17.8 & 64.6 & 66.6 & 65.1 \\
12 & 24.6 & 25.1 & 24.9 & 33.5 & 31.7 & 33.1 \\
13 & 34.8 & 34.3 & 34.2 & 34.0 & 33.7 & 35.1 \\
14 & 34.0 & $28.1^{b}$ & 29.7 & 29.6 & 29.4 & 38.6 \\
15 & 225.0 & 224.2 & 221.3 & 217.9 & 217.9 & 219.2 \\
16 & 47.7 & 48.3 & 47.9 & 49.8 & 49.3 & 49.0 \\
17 & 10.0 & 9.9 & 9.9 & 11.0 & 10.6 & 11.1 \\
18 & 28.1 & 28.2 & 28.1 & 28.1 & 28.1 & 28.0 \\
19 & 15.3 & 15.4 & 16.5 & 16.6 & 16.5 & 18.1 \\
20 & 17.5 & 17.8 & 17.8 & 17.8 & 18.1 & 18.8 \\
\hline
\end{tabular}

$a, b$ These values can be interchanged.

substrate had disappeared, with a new methyl group being observed at $\delta 1.10$ as a $\operatorname{doublet}(\mathrm{J}=7 \mathrm{~Hz})$. Thus, during the incubation or the extraction procedure a rearrangement to a 15-oxo,17-methyl derivative had occurred. The $\mathrm{C}-15$ and $\mathrm{C}-17$ resonances were at $\delta 224.2$ and 9.9 , respectively. On the other hand, the new hydroxyl group was assigned to the $\mathrm{C}-7 \alpha$ position by analogy to the same argument used for compound 5 . Its geminal proton appeared at $\delta 3.93(J=11.6,4.5 \mathrm{~Hz})$. The ${ }^{13} \mathrm{C}-\mathrm{NMR}$ spectrum is listed in Table 2 . Thus, the structure of this product was elucidated as $3 \alpha, 7 \alpha$. dihydroxy-15-oxoent-(16S)-kaurane (8).
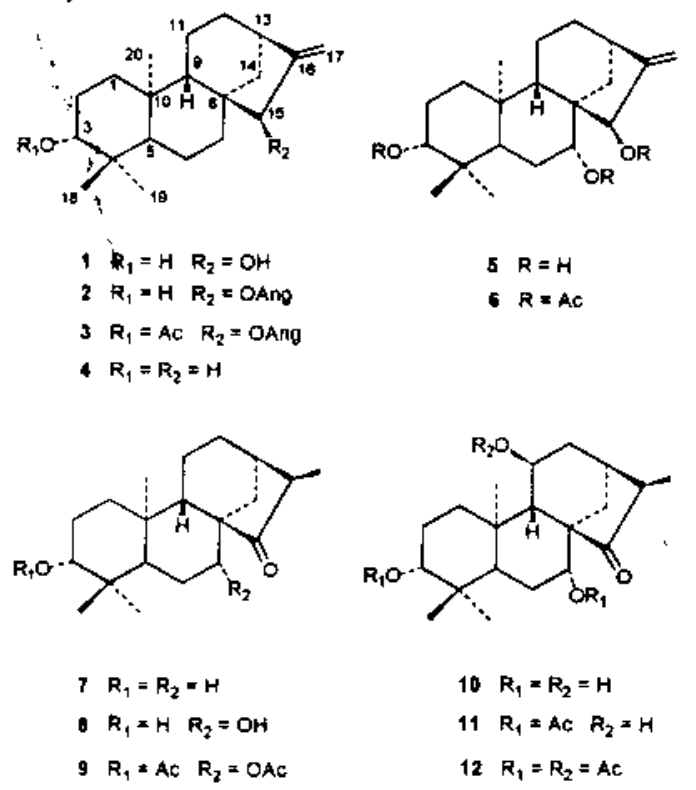

$$
\begin{aligned}
& 10 R_{1}=R_{2}=H \\
& 11 R_{1}=A C R_{2}=H \\
& 12 R_{1}=R_{2}=A C
\end{aligned}
$$
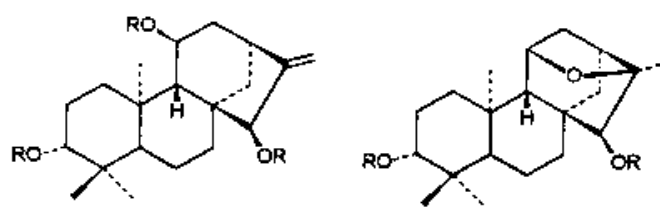

$$
\begin{aligned}
& 13 \quad R=H \\
& 14 R=A C
\end{aligned}
$$

$$
15 R=H
$$$$
16 R=A C
$$

The mixture of the substances 13 and 15 was resolved by acetylation and chromatography. The triacetate 14 and the diacetate 16 were thus obtained in pure form. The EIMS of the triacetate 14 showed no molecular ion, but rather a fragment, formed therefrom by loss of ketene, was observed at $m / z$ 404. Its ${ }^{1} \mathrm{H}-\mathrm{NMR}$ spectrum exhibited three hydrogens geminal to acetyl groups. The first resonated at $\delta 4.51$ (dd, $J=10.8,5.4 \mathrm{~Hz}$ ) and the third at $5.20(1 \mathrm{H}, \mathrm{t}, J=2.6 \mathrm{~Hz})$, and they were assigned to $\mathrm{H}-3(\beta)$ and $\mathrm{H}-15(\alpha)$, respectively, considering that the corresponding carbons were hydroxylated in the substrate. The second geminal proton was located at H-11$(\alpha)$ and resulted from the introduction of a new alcohol group in the fermentation. Its chemical shift $(\delta 5.00)$, the form of the signal (a doublet), and the coupling constant $(J=3.5 \mathrm{~Hz})$ are typical of a hydrogen geminal to an acetyl group at C-11( $\beta)$ in the ent-kaurene class of diterpenoids. ${ }^{1,2}$ The ${ }^{13} \mathrm{C}-\mathrm{NMR}$ spectrum listed in Table 2 is in accordance with this assertion. Therefore, the natural metabolite must be $3 \alpha, 11 \beta, 15 \beta$-trihydroxyent-kaur-16-ene (13).

The diacetate 16 exhibited a molecular formula of $\mathrm{C}_{24} \mathrm{H}_{36} \mathrm{O}_{5}$. Its ${ }^{1} \mathrm{H}-\mathrm{NMR}$ spectrum showed three hydrogens geminal to oxygenated functions, two of which were acetyl groups. One of these signals, $\delta 4.50$ (dd), was analogous to that described for compound $2^{9}$ and consequently was due to $\mathrm{H}-3(\beta)$. Another signal at $\delta$ 4.43 , a singlet, was assigned to the geminal proton in the $15 \beta$-OAc group, considering the form of resonance. The disappearance of the double bond and the resonance of a new third geminal proton at $\delta 4.34$ as a triplet led us to locate an oxygen bridge between $\mathrm{C}-11(\beta)$ and C-16$(\beta)$. This last chemical shift and form of resonance are characteristic of the $\mathrm{H}-11 \alpha$ geminal to this ether function. $^{2}$ The methyl on C-16 resonates at $\delta 1.25$. Thus, the compound isolated from the incubation of 1 was $3 \alpha$,15 $\alpha$-dihydroxy-11 $\beta, 16 \beta$-epoxy-ent-kaurane (15). This substance is probably formed from the product 13 in the treatment of the EtOAc extract with aqueous acid during the isolation procedure and must occur via protonation of the double bond and neutralization of the ion formed at $\mathrm{C}-16$ by the $11 \beta-\mathrm{OH}$.

To the most polar compound isolated was assigned the structure $3 \alpha, 7 \alpha, 11 \beta, 15 \beta$-tetrahydroxy-ent-kaur-16ene (17) on the basis of several considerations. Its molecular formula was determined as $\mathrm{C}_{20} \mathrm{H}_{32} \mathrm{O}_{4}$ by HREIMS. The four oxygens of the molecule were assigned to hydroxyl groups, because this compound formed a tetraacetate. In the ${ }^{1} \mathrm{H}-\mathrm{NMR}$ spectrum of $\mathbf{1 7}$ appeared the protons geminal to four secondary hydroxyl groups, two of which were introduced in the molecule during fermentation. The resonances of their geminal hydrogens at $\delta 3.27$ (dd, $J=11,5 \mathrm{~Hz}$ ) and 4.02 (d, $J=5 \mathrm{~Hz}$ ) permitted the assignment of the new alcohols to positions $\mathrm{C}-7 \alpha$ and $\mathrm{C}-11 \beta$, respectively, by comparing their resonances with those of compounds 5 and 13, which were also isolated in this feeding study. In contrast, these last two metabolites can be considered to be the biogenetic precursors of substance 17 .

Finally, another of the compounds formed in this incubation was $10\left(\mathrm{C}_{20} \mathrm{H}_{32} \mathrm{O}_{4}\right)$. Its ${ }^{1} \mathrm{H}-\mathrm{NMR}$ spectrum was very similar to that of 8 . Thus, the hydrogen geminal to a new hydroxyl group appeared as a doublet at $\delta 3.91(J=4.2 \mathrm{~Hz})$ and at $\delta 5.04(\mathrm{~d}, J=4.1 \mathrm{~Hz})$ in its triacetate (12). The chemical shifts and splitting patterns of these hydrogens in $\mathbf{1 0}$ and $\mathbf{1 2}$ are typical of protons geminal to these oxygenated functions at C-11- 
$(\beta) 1^{1,2}$ Thus, the structure assigned to this metabolite was $3 \alpha, 7 \alpha, 11 \beta$-trihydroxy-15-oxoent-(16S)-kaurane (10).

Compounds 8 and 10 were formed by rearrangement of 5 and 17, respectively. This isomerization can occur either in the incubation or during the isolation after treatment with acid. Apparently, this type of rearrangement occurs only in those metabolites that possess a C-7 $\alpha$ hydroxyl group. Indeed, although after the fermentation the substrate 1 was recovered in almost $50 \%$ yield, its corresponding isomerized product 7 could not be isolated.

At this point and considering that in this first feeding 15-oxo-derivatives were obtained, we decided to incubate a compound of this type such as 7 , which can be obtained by rearrangement of 1 with acid, 9.13 The aim of this part of the work was to compare the results with those obtained in the earlier fermentation.

The second incubation was also made in the presence of AMO 1618. The new substrate (7) was very well metabolized by the fungus, with substance 10 being obtained in major amounts. Other products isolated were $8,20,22,25$, and 27.

Compounds $\mathbf{8}$ and $\mathbf{1 0}$ were identical with those obtained in the feeding of the $15 \beta$-alcohol 1 , as described above. Products 20 and 22 were separately purified as the diacetate 21 and monoacetate 23 , respectively, by acetylation and chromatography.

The diacetate 21 gave a molecular formula of $\mathrm{C}_{24} \mathrm{H}_{36} \mathrm{O}_{5}$. Its ${ }^{1} \mathrm{H}-\mathrm{NMR}$ spectrum showed protons geminal to the $3 \alpha-O A c$ group as well as to a new acetyl group. The latter resonated as a doublet centered at $\delta 5.07$ with a coupling constant of $4.4 \mathrm{~Hz}$. This position and form of resonance are typical of a hydrogen geminal to a C-11 $\beta$ acetoxyl group (see above). Therefore, the corresponding diol, formed in the feeding, was $3 \alpha, 11 \beta$-dihydroxy15-oxo-ent-(16S)-kaurane (20).

The $3 \alpha$-monoacetate $\mathbf{2 3}$ showed in the HREIMS a molecular iom corresponding to $\mathrm{C}_{22} \mathrm{H}_{34} \mathrm{O}_{5}$. Its ${ }^{1} \mathrm{H}-\mathrm{NMR}$ spectrum exhipited, besides the proton geminal to the $3 \alpha$-acetyl group at $\delta 4.42$, two hydrogens geminal to two hydroxyl groups. One of these was assigned to C-11$(\beta)$, because it appeared at $\delta 3.97$ as a doublet, which is characteristic for an $\mathrm{H}-11 \alpha$ proton (see above). The resonance of the other proton at $\delta 4.54$, occurring as a broad singlet, indicated the possible location of the corresponding hydroxyl at $\mathrm{C}-1(\beta), \mathrm{C}-6(\alpha)$, or $\mathrm{C}-7(\beta)$. The $\mathrm{C}-6 \alpha$ position was selected because it cannot be acetylated with $\mathrm{Ac}_{2} \mathrm{O}$-pyridine at $60^{\circ} \mathrm{C}$ for $12 \mathrm{~h}$, as a consequence of steric impediment from the C-19 and C-20 methyls. ${ }^{14}$ In this reaction the diacetate 24 was formed. The assignments in the ${ }^{13} \mathrm{C}-\mathrm{NMR}$ spectra of 23 and 24 also confirmed their structures (Tables 2 and 3 ). Thus, the metabolite isolated from the feeding was a triol: $3 \alpha, 6 \alpha, 11 \beta$-trihydroxy-15-oxo-ent-(16S)-kaurane (22).

Another compound isolated in the fermentation was $3 \alpha, 6 \beta, 7 \alpha$-trihydroxy-15-oxo-ent-(16S)-kaurane (25). Its HREIMS was in accordance with the formula $\mathrm{C}_{20} \mathrm{H}_{32} \mathrm{O}_{4}$. The ${ }^{1} \mathrm{H}-\mathrm{NMR}$ spectrum showed geminal hydrogens of the hydroxyl groups at C-6 and C-7, which appeared as a triplet at $\delta 3.83(J=9.6 \mathrm{~Hz})$ and a doublet at $3.74(J$ $=9.6 \mathrm{~Hz}$ ), respectively, indicating $6 \beta$ and $7 \alpha$ stereochemistry for these two hydroxyls. When the spectrum was run in $\mathrm{C}_{6} \mathrm{D}_{6}, \mathrm{H}-5$ resonated at $\delta 0.90$ as a doublet, and $H-6(t)$ and $H-7(d)$ appeared more separated at $\delta$
Table 3. ${ }^{13}$ C-NMR Data of Compounds $24-27$ and 29

\begin{tabular}{crrrrr}
\hline carbon & $\mathbf{2 4}$ & $\mathbf{2 5}$ & $\mathbf{2 6}$ & $\mathbf{2 7}$ & $\mathbf{2 9}$ \\
\hline 1 & 39.3 & 37.3 & 36.8 & 37.7 & 37.3 \\
2 & 23.4 & 26.6 & 22.7 & 26.8 & 23.1 \\
3 & 80.2 & 78.5 & 80.0 & 78.5 & 80.1 \\
4 & 37.9 & 41.4 & 37.6 & 38.6 & 37.6 \\
5 & 54.7 & 55.9 & 55.1 & 54.1 & 54.0 \\
6 & 67.2 & 72.0 & 71.0 & 18.3 & 18.1 \\
7 & 42.6 & 76.3 & 74.5 & 36.1 & 34.6 \\
8 & 48.9 & 57.4 & 56.3 & 54.7 & 50.5 \\
9 & 59.0 & 50.7 & 50.5 & $65.4^{a}$ & 60.7 \\
10 & 38.6 & 39.2 & 41.2 & 38.8 & 38.2 \\
11 & 66.8 & 17.7 & 17.5 & $65.3^{a}$ & 66.5 \\
12 & 31.3 & 25.0 & 24.7 & 33.3 & 33.0 \\
13 & 24.9 & 34.2 & 34.1 & 41.4 & 38.2 \\
14 & 38.4 & 29.0 & 30.2 & 34.7 & 34.6 \\
15 & 221.4 & 222.7 & 219.4 & $\mathbf{n . 0} . .^{b}$ & 205.3 \\
16 & 48.9 & 47.7 & 47.4 & n.o. & 86.4 \\
17 & 10.7 & 10.0 & 9.9 & 19.9 & 15.8 \\
18 & 28.0 & 30.7 & 30.1 & 28.1 & 28.1 \\
19 & 18.1 & 15.6 & 16.9 & 15.3 & 16.4 \\
20 & 19.1 & 18.9 & 18.8 & 17.6 & 17.8 \\
\hline
\end{tabular}

${ }^{a}$ These values can be interchanged. ${ }^{b}$ n.o. $=$ Signal not observed.

3.65 and 3.82 , respectively, which permitted double resonance experiments to be performed. Thus, irradiation of H-6 collapsed the H-5 and H-7 doublets to singlets. The assignment of the ${ }^{13} \mathrm{C}-\mathrm{NMR}$ spectrum of $\mathbf{2 5}$, and that of its triacetate $\mathbf{2 6}$ (Table 3 ), also confirmed their structures.

Finally, we identified a minor compound, to which the structure of $3 \alpha, 11 \beta, 16 \alpha$-trihydroxy-15-oxo-ent-(16S)kaurane (27) was given. The ${ }^{1} \mathrm{H}-\mathrm{NMR}$ spectrum of its $3 \alpha, 11 \beta$-diacetate (28) was similar to that of 21 , with the main difference being that the $\mathrm{C}-17$ methyl resonated as a singlet at $\delta 1.54$, which indicated that $\mathrm{C}-16$ bore an oxygen function, in this case a hydroxyl group, because an ether bridge between $C-11(\beta)$ and $C-16(\beta)$ can be ruled out considering the molecular formula obtained of $\mathrm{C}_{24} \mathrm{H}_{36} \mathrm{O}_{6}$. The chemical shift and splitting pattern of $\mathrm{H}-11(\alpha)$ in 28, which appeared as a doublet at $\delta 5.05$, were similar to those of 21 , also a doublet at $\delta 5.07$, thereby confirming this assertion. The stereochemistry of the alcohol at $\mathrm{C}-16$ was assigned as $\alpha$ considering that in this type of compound the hydroxylation occurs from the $\alpha$ face. ${ }^{15}$ The assignments of the ${ }^{13} \mathrm{C}-\mathrm{NMR}$ resonances of the alcohol 27 and its triacetate $\mathbf{2 9}$ are in accordance with their structures and are included in Table 3 .

The results of the two fermentation carried out in the present investigation led to several considerations. First, although 3a-hydroxy-ent-kaur-16-ene (4) is not transformed by $G$. fujikuroi, more polar derivatives such as the $3 \alpha, 15 \beta$-diol 1 or the $3 \beta-\mathrm{OH}, 15$-oxo derivative 7 can be biotransformed by this fungus. Second, the presence of a $15 \beta$-hydroxyl or a 15-oxo group directs the hydroxylation at $\mathrm{C}-11(\beta)$ or $\mathrm{C}-7(\alpha)$. For these processes to occur the presence is also necessary in the molecule of an inhibitory group of the oxidation at C-19, such as a $3 \alpha-O H$. It is known that $15 \beta, 19$-dihydroxy-ent-kaur16-ene ${ }^{4-6}$ or 15 -oxo-ent-kaurane, ${ }^{16}$ which have no inhibitory group, can be oxidized at C-19 and consequently transformed into $15 \beta$-hydroxygibberellins or 15-oxogibberellins. Third, the results of these two incubations are analogous to those previously obtained with $15 \alpha$ hydroxy-ent-kaur-16-ene derivatives. ${ }^{1,2}$ However, in this last case, the same group $(15 \alpha-\mathrm{OH})$ operates as a partial inibitor of C-19 oxidation and as a directing group of the hydroxylation at C-7 or C-11. Fourth, these 


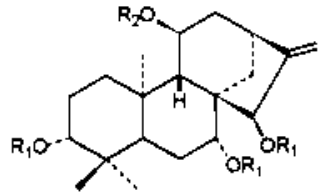

$17 R_{1}=R_{2}=H$

$10 R_{1}=A C \quad R_{2}=H$

18 $R_{1}=R_{2}=A C$
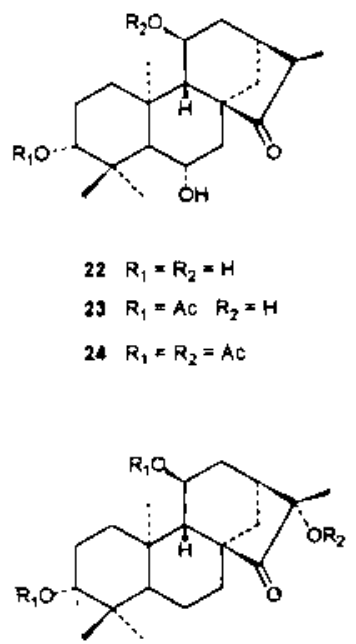

$27 R_{1}=R_{2}=H$

28 $R_{1}=A C \quad R_{2}=H$

29 $R_{1}=R_{2} \neq A C$

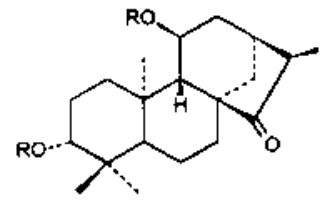

$20 \mathrm{R}=\mathrm{H}$

$21 \mathrm{R} \times \mathrm{AC}$

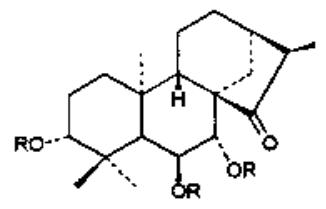

$26 R=H$

$26 R=A C$

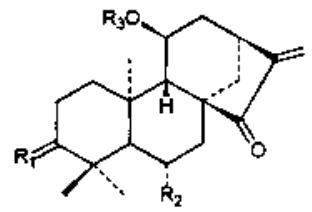

30 $R_{1}=a-O H, H \quad R_{2}=H \quad R_{3}=A C$

$31 \quad R_{1}=O \quad R_{2}=O H \quad R_{3}=H$ conclusions are also valid for the biotransformation of 15-oxo-ent-kaur-16-ene derivatives, because these compounds are first metabolized by the fungus to the corresponditig hydrogenated compounds, the 15-oxoent(16S)-kaurahes. ${ }^{16}$ Finally, the products obtained in these incubations with $G$. fujikuroi can be useful for the preparation of compunds such as isodopharicin A (30), obtained from Isodon pharicus, ${ }^{17}$ or inflexarabdonin I (31), isolated from Rabdosia inflexa. ${ }^{18}$

\section{Experimental Section}

General Experimental Procedures. Mps were determined with a Reichert Thermovar apparatus and are uncorrected. ${ }^{1} \mathrm{H}^{+}$and ${ }^{13} \mathrm{C}-\mathrm{NMR}$ spectra were recorded in $\mathrm{CDCl}_{3}$ solution, unless stated otherwise, at 200.13 and $50.32 \mathrm{MHz}$, respectively, with a Bruker AC 200 spectrometer. LREIMS and HREIMS were obtained on a Shimadzu QP 2000 and a VG Micromass ZAF-2F mass spectrometer, respectively. Column chromatography was performed with $\mathrm{Si}$ gel Merck $(0.05-$ $0.2 \mathrm{~mm}$ ).

Microorganism. The fungus strain was Gibberella fujikuroi IMI 58289 from the International Mycological Institute, Englefield Green, Egham, Surrey, U.K.

Incubation of 1 . The fungus, inhibited with $5 \times$ $10^{-5}$ M AMO 1618 ( $2^{\prime}$ 'isopropyl-4'-(trimethylammonium chloride)-5'-methylphenylpiperidine-1-carboxylate), was grown in shake culture at $25{ }^{\circ} \mathrm{C}$ for 2 days in $65-75$ conical flasks ( $250 \mathrm{~mL}$ ), each containing sterile medium $(50 \mathrm{~mL}){ }^{19}$ The substrate (1) $(250 \mathrm{mg})$ in EtOH $(15 \mathrm{~mL})$ was distributed equally between the flasks, and the incubation was allowed to continue for a further 6 days.
The broth was filtered, adjusted to $\mathrm{pH} 2$ with dilute $\mathrm{HCl}$, and extracted with EtOAc. The mycelium was treated with liquid $\mathrm{N}_{2}$, crushed with a mortar, and extracted with EtOAc. The two extracts were combined and separated into acidic and neutral fractions with $\mathrm{NaH}-$ $\mathrm{CO}_{3}$. The acidic fraction was methylated with $\mathrm{CH}_{2} \mathrm{~N}_{2}$, but no acidic kaurene derivatives were obtained.

The neutral fraction was chromatographed on Si gel eluting with petroleum ether-EtOAc mixtures, giving starting material (1) (110 mg), 3 $\alpha, 7 \alpha$-dihydroxy-15-oxo-

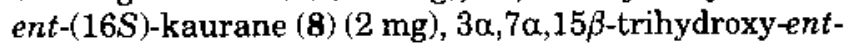
kaur-16-ene (5) (7 mg), a mixture of $3 \alpha, 15 \beta$-dihydroxy$11 \beta, 16 \beta$-epoxy-ent-kaurane (15) and $3 \alpha, 11 \beta, 15 \beta$-trihydroxy-ent-16-ene (13) ( $4 \mathrm{mg}$ ), $3 \alpha, 7 \alpha, 11 \beta$-trihydroxy15-oxo-ent-(16S)-kaurane (10) (12 mg), and $3 \alpha, 7 \alpha, 11 \beta,-$ $15 \beta$-tetrahydroxy-ent-kaur-16-ene (17) (25 mg).

3a,7a,15p-Trihydroxy-ent-kaur-16-ene (5): ${ }^{1} \mathrm{H}$ NMR $(200 \mathrm{MHz}) \delta 0.79,1.00,1.05(3 \mathrm{H}$ each, s), $2.72(1 \mathrm{H}, \mathrm{br}$ $\mathrm{s}, \mathrm{H}-13), 3.21(1 \mathrm{H}$, dd, $J=10.4,6 \mathrm{~Hz}, \mathrm{H}-3), 3.57(1 \mathrm{H}$, dd, $J=11.6,4.5 \mathrm{~Hz}, \mathrm{H}-7), 4.47(1 \mathrm{H}, \mathrm{t}, J=2.7 \mathrm{~Hz}, \mathrm{H}-15)$, $4.99(1 \mathrm{H}, \mathrm{d}, J=2.7 \mathrm{~Hz}, \mathrm{H} \cdot 17), 5.10(1 \mathrm{H}, \mathrm{br} \mathrm{s}, \mathrm{H}-17)$; ${ }^{13} \mathrm{C}-\mathrm{NMR}$ data, see Table 1; EIMS $m / z[\mathrm{M}]^{+} 320(19)$, 302 (40), 287 (22), $284(18), 269$ (27), 262 (46), 251 (9), $227(10), 213(23), 199(17)$; HREIMS $m / z 320.2351[\mathrm{M}]^{+}$, $\mathrm{C}_{20} \mathrm{H}_{32} \mathrm{O}_{3}$ requires 320.2351 .

Triacetate 6: ${ }^{1} \mathrm{H}$ NMR $(200 \mathrm{MHz}) \delta 0.86,0.89,1.12$ (3H each, s) , 2.06, 2.07, 2.16 (3H each, $\mathrm{s},-\mathrm{OAc}), 2.74$ (1H, br s, H-13), 4.49 (2H, dd overlapped, $\mathrm{H}-3$ and $\mathrm{H}-7$ ), $4.92(1 \mathrm{H}$, br s, H-17), $4.97(1 \mathrm{H}, \mathrm{d}, J=2.6 \mathrm{~Hz}, \mathrm{H}-17)$, $5.46(1 \mathrm{H}, \mathrm{t}, J=2.6 \mathrm{~Hz}, \mathrm{H}-15) ;{ }^{13} \mathrm{C}$ NMR data, see Table 1; EIMS $m / z\left[\mathrm{M}-\mathrm{C}_{2} \mathrm{H}_{2} \mathrm{O}\right]^{+} 404(10), 386(24), 344(100)$, 326 (42), $311(26), 284(58), 269$ (33), $266(29), 251(30)$, 241 (29), 227 (15), 199 (12); HREIMS $m / z$ 404.2552 [M $\left.-\mathrm{C}_{2} \mathrm{H}_{2} \mathrm{O}\right]^{+}, \mathrm{C}_{24} \mathrm{H}_{36} \mathrm{O}_{5}$ requires 404.2562 .

3 $\alpha, 7 \alpha$-Dihydroxy-15-oxo-ent-(16S)-kaurane (8): white crystals (petroleum ether/EtOAc); mp 198-200 ${ }^{\circ} \mathrm{C} ;{ }^{1} \mathrm{H}$ NMR $(200 \mathrm{MHz}) \delta 0.79,1.00,1.08$ (3H each, s), 1.10 (3H, d, $J=7 \mathrm{~Hz}, \mathrm{H}-17$ ), 2.48 (1H, br s, H-13), 3.13 $(1 \mathrm{H}, \mathrm{dd}, J=10.2,6 \mathrm{~Hz}, \mathrm{H}-3), 3.93(1 \mathrm{H}, \mathrm{dd}, J=11.6$, $4.5 \mathrm{~Hz}, \mathrm{H}-7)$; ${ }^{13} \mathrm{C}-\mathrm{NMR}$ data, see Table 2 ; EIMS $\mathrm{m} / \mathrm{z}[\mathrm{M}]^{+}$ $320(89), 302(21), 287(9), 284(6), 269(8), 262$ (100), 256 (2), 244 (7), 241 (7), 211 (4); HREIMS $m / z 320.2350$ $[\mathrm{M}]^{+}, \mathrm{C}_{20} \mathrm{H}_{32} \mathrm{O}_{3}$ requires 320.2351 .

Diacetate 9: white crystals (petroleum ether/EtOAc); $\mathrm{mp} 172-174{ }^{\circ} \mathrm{C} ;{ }^{1} \mathrm{H}$ NMR (200 MHz) $\delta 0.85,0.90,1.12$ (3H each, s), 1.09 (3H, d, $J=7 \mathrm{~Hz}, \mathrm{H}-17), 1.95,2.04$ (3H each, s), 2.48 ( $1 \mathrm{H}$, br s, H-13), $4.44(1 \mathrm{H}, \mathrm{dd}, J=11$, $5 \mathrm{~Hz}, \mathrm{H}-3)$, and $4.98(1 \mathrm{H}, \mathrm{dd}, J=11.6,4.4 \mathrm{~Hz}, \mathrm{H}-7)$; ${ }^{13} \mathrm{C}$-NMR data, see Table 2; EIMS $m / z[M]+404(3), 362$ (8), 346 (15), 344 (15), 304 (45), 284 (22), 269 (36), 256 (12), 241 (27), 227 (41), 211 (11); HREIMS $m / z 404.2561$ $[\mathrm{M}]^{+}, \mathrm{C}_{24} \mathrm{H}_{36} \mathrm{O}_{5}$ requires 404.2562 .

$3 \alpha, 7 \alpha, 11 \beta$-Trihydroxy-15-oxo-ent-(16S)-kaurane (10): white crystals (petroleum ether/EtOAc); mp 227$229^{\circ} \mathrm{C}$; ${ }^{1} \mathrm{H}$ NMR $(200 \mathrm{MHz}) \delta 0.79,0.99$ and $1.01(3 \mathrm{H}$ each, s), $1.26(3 \mathrm{H}, \mathrm{d}, J=7 \mathrm{~Hz}, \mathrm{H}-17), 2.47(1 \mathrm{H}, \mathrm{br} \mathrm{s}$, H-13), $3.24(1 \mathrm{H}$, dd, $J=10.8,5.5 \mathrm{~Hz}, \mathrm{H}-3), 3.91(1 \mathrm{H}, \mathrm{d}$, $J=4.2 \mathrm{~Hz}, \mathrm{H}-11$ ), 3.96 (1H, dd, $J=11.5,4.5 \mathrm{H}-7$ ); EIMS $\mathrm{m} / \mathrm{z}[\mathrm{M}]^{+} 336(5), 318(8), 300(7), 285(8), 282(2), 278$ (2), 267 (4), 262 (7), 260 (3), 245 (6), 227 (9), 209 (4), 199 (5); HREMS $m / z 336.2291[\mathrm{M}]^{2}, \mathrm{C}_{20} \mathrm{H}_{32} \mathrm{O}_{4}$ requires 336.2300 .

3a,7a-Diacetate (11): obtained by treatment with $\mathrm{Ac}_{2} \mathrm{O} / \mathrm{C}_{6} \mathrm{H}_{5} \mathrm{~N}(2: 1)$ at room temperature for $12 \mathrm{~h} ;{ }^{1} \mathrm{H}$ NMR (200 MHz) $\delta 0.85,0.93,1.04$ (3H each, s), 1.26 
$(3 \mathrm{H}, \mathrm{d}, J=7 \mathrm{~Hz}, \mathrm{H}-17), 1.96$ and 2.05 (3H each, s), 2.48 $(1 \mathrm{H}, \mathrm{br} \mathrm{s}, \mathrm{H}-13), 3.93(1 \mathrm{H}, \mathrm{d}, J=4.1 \mathrm{~Hz}, \mathrm{H}-11), 4.49$ $(1 \mathrm{H}, \mathrm{dd}, J=11.5,5 \mathrm{~Hz}, \mathrm{H}-3), 5.03(1 \mathrm{H}, \mathrm{dd}, J=11.5$, $4.5 \mathrm{~Hz}, \mathrm{H}-7) ;{ }^{13} \mathrm{C}-\mathrm{NMR}$ data, see Table 2, EIMS $m / z$ [M $\left.-\mathrm{C}_{2} \mathrm{H}_{2} \mathrm{O}\right\}^{+} 378$ (5), $360(6), 320$ (11), 300 (21), 285 (14), 267 (3), 227 (100), 211 (15); HREIMS $m / z$ 378.2400 [M - $\left.\mathrm{C}_{2} \mathrm{H}_{2} \mathrm{O}\right]^{+}, \mathrm{C}_{22} \mathrm{H}_{34} \mathrm{O}_{5}$ requires 378.2406.

Triacetates 12: obtained warming the diacetate with $\mathrm{Ac}_{2} \mathrm{O}-\mathrm{C}_{5} \mathrm{H}_{5} \mathrm{~N}(2: 1)$ at $80^{\circ} \mathrm{C}$ for $2 \mathrm{~h} ;{ }^{1} \mathrm{H}$ NMR $(200 \mathrm{MHz})$ $\delta 0.84,0.90,1.08(3 \mathrm{H}$ each, s), $1.18(3 \mathrm{H}, \mathrm{d}, J=7 \mathrm{~Hz}$, $\mathrm{H}-17$ ), 1.95, 1.96, 2.04 (3H each, s), 2.51 (1H, br s, H-13), $4.45(1 \mathrm{H}, \mathrm{dd}, J=11.5,5 \mathrm{~Hz}, \mathrm{H}-3), 5.00(1 \mathrm{H}, \mathrm{dd}, J=$ $11.5,4.5 \mathrm{~Hz}, \mathrm{H}-7), 5.04(1 \mathrm{H}, \mathrm{d}, J=4.1 \mathrm{~Hz}, \mathrm{H}-11) ;{ }^{13} \mathrm{C}-$ NMR, see Table 2; EIMS $m / z$ [M] ${ }^{+} 462(1), 420(16), 402$ (5), $378(4), 360(12), 342(22), 332(30), 300(32), 282$ (81), $267(29), 239(21), 227(97), 211(26), 199(15)$; HREIMS $m / z$ 462.2628 [M] $]^{+}, \mathrm{C}_{26} \mathrm{H}_{38} \mathrm{O}_{7}$ requires 462.2617 .

Compounds 13 and 15. The mixture of these two metabolites was resolved by acetylation, at room temperature, and chromatography in $\mathrm{Si}$ gel. In this way the triacetate 14 and the diacetate 16 were obtained.

$3 \alpha, 11 \beta, 15 \beta$-Triacetoxy ent-kaur-16-ene (14): ${ }^{1} \mathrm{H}$ NMR (200 MHz) $\delta 0.85,0.87,1.01$ (3H each, s), 1.91, $2.05,2.18(3 \mathrm{H}$ each, s), $2.67(1 \mathrm{H}$, br $\mathrm{s}, \mathrm{H}-13), 4.51(1 \mathrm{H}$, $\mathrm{dd}, J=10.8,5.4 \mathrm{~Hz}, \mathrm{H}-3), 4.88(1 \mathrm{H}$, br s, H-17), 4.94 (1H, d, $J=2.5 \mathrm{~Hz}, \mathrm{H}-17), 5.00$ (1H, d, $J=3.5 \mathrm{~Hz}, \mathrm{H}-11$ ), $5.20(1 \mathrm{H}, \mathrm{t}, J=2.6 \mathrm{~Hz}, \mathrm{H}-15) ;{ }^{13} \mathrm{C}-\mathrm{NMR}$ data, see Table 1; EIMS $m / z$ [M $\left.-\mathrm{C}_{2} \mathrm{H}_{2} \mathrm{O}\right]^{+} 404(7), 386(20), 344(60)$, $326(36), 311$ (51), $284(65), 269$ (48), 266 (33), 251 (61), 241 (33), 211 (25), 199 (17); HREIMS $m / z$ 404.2563 [M $-\mathrm{C}_{2} \mathrm{H}_{2} \mathrm{O}^{+}, \mathrm{C}_{24} \mathrm{H}_{36} \mathrm{O}_{5}$ requires 404.2562 .

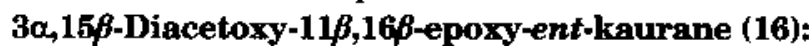
${ }^{1} \mathrm{H}$ NMR $(200 \mathrm{MHz}) \delta 0.88(6 \mathrm{H}, \mathrm{s}), 1.11,1.25$ (3H each, s), 2.06, 2.22 (3H each, s), $4.34(1 \mathrm{H}, \mathrm{t}, \mathrm{H}-11), 4.43(1 \mathrm{H}$, $\mathrm{s}, \mathrm{H}-15)$ and $4.50(\mathrm{HH}, \mathrm{dd}, J=10,6 \mathrm{~Hz}, \mathrm{H}-3)$; ${ }^{1} \mathrm{H}$ NMR $\left(200 \mathrm{MHz}, \mathrm{C}_{6} \mathrm{D}_{6}\right) \delta 0.73,0.80,0.84,1.42$ (3H each, s), $1.71,1.90$ (3H each, s), $4.16(1 \mathrm{H}, \mathrm{t}, \mathrm{H}-11), 4.55(1 \mathrm{H}, \mathrm{dd}$, $J=4.9,11 \mathrm{~Hz}, \mathrm{H}-3), 4.58(1 \mathrm{H}, \mathrm{s}, \mathrm{H}-15)$; EIMS $m / z[\mathrm{M}]^{+}$ 404 (4), 362 (64), 344 (17), 329 (11), 301 (11), 284 (14), 269 (14), 251'(7), 229 (13), 199 (6); HREIMS $\mathrm{m} / \mathrm{z}$ $404.2555[\mathrm{M}]^{+}, \mathrm{C}_{24} \mathrm{H}_{36} \mathrm{O}_{5}$ requires 404.2562 .

$3 \alpha, 7 \alpha, 11 \beta, 15 \beta$-Tetrahydroxy-ent-kaur-16-ene (17): white crystals (petroleum ether/EtOAc): mp 259-262 ${ }^{\circ} \mathrm{C}$; ${ }^{1} \mathrm{H}$ NMR $(200 \mathrm{MHz}) \delta 0.80,0.97,1.02$ (3H each, s), $2.70(1 \mathrm{H}$, br s, H-13), $3.27(1 \mathrm{H}, \mathrm{dd}, J=11,5 \mathrm{~Hz}, \mathrm{H}-7)$, $3.68(1 \mathrm{H}, \mathrm{dd}, J=11.5,5 \mathrm{~Hz}, \mathrm{H}-3), 4.02(1 \mathrm{H}, \mathrm{d}, J=5$ $\mathrm{Hz}, \mathrm{H}-11), 4.50(1 \mathrm{H}, \mathrm{t}, J=2.6 \mathrm{~Hz}, \mathrm{H}-15), 5.07(1 \mathrm{H}, \mathrm{d}, J$ $=2.6 \mathrm{~Hz}, \mathrm{H}-17), 5.15\left(1 \mathrm{H}\right.$, br s, H-17); ${ }^{13} \mathrm{C}-\mathrm{NMR}$ data, see Table 1; EIMS $m / z$ [M] 336 (19), 321 (30), 318 (31), $303(12), 300(23), 285(27), 282(7), 267(19), 264(5)$, 262 (32), 239 (15), 227 (24), 199 (15); HREIMS $\mathrm{m} / \mathrm{z}$ $336.2298[\mathrm{M}]^{+}, \mathrm{C}_{20} \mathrm{H}_{32} \mathrm{O}_{4}$ requires 336.2300 .

Acetylation of 17. Treatment of 17 with $\mathrm{Ac}_{2} \mathrm{O}-$ $\mathrm{C}_{5} \mathrm{H}_{5} \mathrm{O}(2: 1)$ at $80^{\circ} \mathrm{C}$ for $4 \mathrm{~h}$ gave a mixture of two compounds, which were chromatographed over Si gel eluting with petroleum ether-EtOAc (6.4) to afford the tetraacetate 19.

Tetraacetate 19: ${ }^{1} \mathrm{H}$ NMR (200 MHz) $\delta 0.90,0.85$, 1.05 ( $3 \mathrm{H}$ each, $\mathrm{s}$ ), 1.91, 2.06, 2.09, 2.16 (3H each, s), 2.72 $(1 \mathrm{H}$, br s, $\mathrm{H}-13), 4.52$ (2H, signals overlapped, $\mathrm{H}-3$ and $\mathrm{H}-7), 4.88(1 \mathrm{H}, \mathrm{br} \mathrm{s}, \mathrm{H}-17), 4.97(1 \mathrm{H}, \mathrm{d}, J=2.6 \mathrm{~Hz}$, $\mathrm{H}-17), 5.02(1 \mathrm{H}, \mathrm{d}, J=4.4 \mathrm{~Hz}, \mathrm{H}-11), 5.52(1 \mathrm{H}, \mathrm{d}, J=$ $2.6 \mathrm{~Hz}, \mathrm{H}-15)$; ${ }^{13} \mathrm{C}-\mathrm{NMR}$ data, see Table 1 ; EIMS $m / z$ $\left[\mathrm{M}-\mathrm{C}_{2} \mathrm{H}_{2} \mathrm{O}\right]^{+} 462(8), 444(11), 402(8), 384(18), 342$ (43), $324(42), 309$ (79), $281(100), 267$ (56), 249 (29),
239 (42), 211 (25), 199 (15); HREIMS $m / z$ 462.2624 [M $\left.-\mathrm{C}_{2} \mathrm{H}_{2} \mathrm{O}\right]^{+}, \mathrm{C}_{26} \mathrm{H}_{38} \mathrm{O}_{7}$ requires 462.2617. Further elution gave the $3 \alpha, 7 \alpha, 15 \beta$-triacetate 18 .

Compound 18: ${ }^{1} \mathrm{H}$ NMR (200 MHz) $\delta 0.85,0.91,0.99$ (3H each, s), 2.06, 2.10, 2.21 (3H each, s), $2.77(1 \mathrm{H}, \mathrm{br}$ $\mathrm{s}, \mathrm{H}-13), 3.80(1 \mathrm{H}$, br s, H-11), $4.54(2 \mathrm{H}$, signals overlapped, $\mathrm{H}-3$ and $\mathrm{H}-7$ ), 4.99 (1H, br s, H-17), 5.20 $(1 \mathrm{H}, \mathrm{d}, J=2.6 \mathrm{~Hz}, \mathrm{H}-17), 5.63(1 \mathrm{H}, \mathrm{d}, J=2.6 \mathrm{~Hz}, \mathrm{H}-15)$.

Incubation of 7 . The substrate (7) $(240 \mathrm{mg})$ was incubated with $G$. fujikuroi as described above. The broth and mycelium were extracted with EtOAc without any acidification. The two extracts were combined, dried, and concentrated. Chromatography on Si gel, eluting with petroleum ether-EtOAc mixtures gave the starting material (7) $(30 \mathrm{mg}), 3 \alpha, 7 \alpha$-dihydroxy-15-0xoent-(16S)-kaurane (8) (19 mg), a mixture of $3 \alpha, 11 \beta$ dihydroxy-15-oxo-ent-(16S)-kaurane (20) and $3 \alpha, 6 \alpha, 11 \beta$ trihydroxy-15-oxo-ent-(16S)-kaurane (22) (5 mg), $3 \alpha$, $6 \beta, 7 \alpha$-trihydroxy-15-oxo-ent -(16S)-kaurane $(25)(5 \mathrm{mg})$, $3 \alpha, 11 \beta, 16 \beta$-trihydroxy-15-oxo-ent-(15S)-kaurane (27) (3 $\mathrm{mg}$ ), and $3 \alpha, 7 \alpha, 11 \beta$-trihydroxy-15-oxo-ent-(16S)-kaurane (10) $(98 \mathrm{mg})$. The metabolites $(8)$ and $(10)$ were identical to those obtained in the feeding of 1 , as described above.

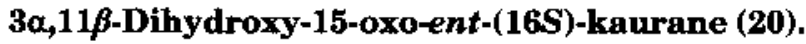
Compound 20 was purified by acetylation and chromatography.

Diacetate (21): ${ }^{1} \mathrm{H}$ NMR $(200 \mathrm{MHz}) \delta 0.85,0.88,1.05$ (3H each, s), 1.96, 2.04 (3H each, s), 4.46 (1H, dd, $J=$ $11.5,5 \mathrm{~Hz}, \mathrm{H}-3), 5.07(1 \mathrm{H}, \mathrm{d}, J=4.4 \mathrm{~Hz}, \mathrm{H}-11)$; EIMS $m / z[\mathrm{M}]^{+} 404(2), 376(4), 362(12), 344(57), 332(20)$, 304 (18), 302 (18), 287 (36), 284 (48), 269 (100), $256(15)$, 241 (36), 227 (58), 211 (80); HREIMS $m / z 404.2548[\mathrm{M}]^{+}$, $\mathrm{C}_{24} \mathrm{H}_{36} \mathrm{O}_{5}$ requires 404.2562 .

$3 \alpha, 6 \alpha, 11 \beta$-Trihydroxy-15-oxo-ent-(16S)-kaurane (22). Compound 22 was purified by acetylation, at room temperature, and chromatograpy affording the $3 \alpha-$ monoacetate (23).

Compound 23: ${ }^{1} \mathrm{H}$ NMR ( $\left.200 \mathrm{MHz}\right) \delta 0.97,1.23,1.39$ ( $3 \mathrm{H}$ each, s), $1.28(3 \mathrm{H}, \mathrm{d}, J=7 \mathrm{~Hz}, \mathrm{H}-17), 2.07(3 \mathrm{H}, \mathrm{s})$, $2.16(1 \mathrm{H}, \mathrm{m}, \mathrm{H} \cdot 16), 3.97(1 \mathrm{H}, \mathrm{d}, J=4.8 \mathrm{~Hz}, \mathrm{H}-11), 4.42$ $(1 \mathrm{H}, \mathrm{dd}, J=9,7 \mathrm{~Hz}, \mathrm{H}-3), 4.54(1 \mathrm{H}, \mathrm{br} \mathrm{s}, \mathrm{H}-6)$; ${ }^{13}$ C-NMR data, see Table 2; EIMS $m / z$ [M] ${ }^{+} 378$ (1), 360 (4), 332 (1), 318 (5), 303 (29), 300 (19), 285 (50), 282 (1), 257 (15), 245 (12), 239 (6), 227 (49), 211 (48), 199 (7); HREIMS $m / z$ 378.2397 $[\mathrm{M}]^{+}, \mathrm{C}_{22} \mathrm{H}_{34} \mathrm{O}_{5}$ requires 378.2406 .

$3 \alpha, 11 \beta$-Diacetate (24): obtained by acetylation of 23 at $60^{\circ} \mathrm{C}$ for $12 \mathrm{~h} ;{ }^{1} \mathrm{H}$ NMR $(200 \mathrm{MHz}) \delta 0.96,1.23,1.43$ (3H each, s), $1.20(3 \mathrm{H}, \mathrm{d}, J=7 \mathrm{~Hz}, \mathrm{H}-17), 1.96,2.06$ (3H each, s), $2.49(1 \mathrm{H}$, br s, H-13), $4.40(1 \mathrm{H}, \mathrm{dd}, J=9$, $7 \mathrm{~Hz}, \mathrm{H}-3), 4.55(1 \mathrm{H}, \mathrm{br} \mathrm{s}, \mathrm{H}-6), 5.10(1 \mathrm{H}, \mathrm{d}, J=4.8 \mathrm{~Hz}$, $\mathrm{H}-11$ ); ${ }^{13} \mathrm{C}$ NMR data, see Table 3 ; EIMS $m / z$ [M $\left.\mathrm{C}_{2} \mathrm{H}_{2} \mathrm{O}\right]^{+} 378(2), 360(37), 342(1), 332(7), 300(30), 285$ (53), 282 (30), $272(17), 267$ (20), 257 (19), 227 (36), 209 (31); HREIMS $m / z$ 378.2401 [M $\left.-\mathrm{C}_{2} \mathrm{H}_{2} \mathrm{O}\right]^{+}, \mathrm{C}_{22} \mathrm{H}_{34} \mathrm{O}_{5}$ requires 378.2406 .

$3 \alpha, 6 \beta, 7 \alpha$-Trihydroxy-15-oxo-ent-(16S)-kaurane (25): ${ }^{1} \mathrm{H}$ NMR $(200 \mathrm{MHz}) \delta 1.00(6 \mathrm{H}, \mathrm{s}), 1.11(3 \mathrm{H}, \mathrm{d}, J$ $=7 \mathrm{~Hz}, \mathrm{H}-17)$, and $1.16(3 \mathrm{H}, \mathrm{s}), 2.25(1 \mathrm{H}, \mathrm{m}, \mathrm{H}-16), 2.47$ (1H, br s, H-13), $3.20(1 \mathrm{H}, \mathrm{dd}, J=10.6,5.8 \mathrm{~Hz}, \mathrm{H}-3$ ), $3.74(1 \mathrm{H}, \mathrm{d}, J=9.6 \mathrm{~Hz}, \mathrm{H}-7)$, and $3.83(1 \mathrm{H}, \mathrm{t}, J=9.6$, $\mathrm{H}-6) ;{ }^{1} \mathrm{H}$ NMR $\left(200 \mathrm{MHz}, \mathrm{C}_{6} \mathrm{D}_{6}\right) \delta 0.83,1.00,1.03(3 \mathrm{H}$ each, s), $1.01(3 \mathrm{H}, \mathrm{d}, J=7 \mathrm{~Hz}, \mathrm{H}-17), 0.90(1 \mathrm{H}, \mathrm{d}, J=$ $10.2, \mathrm{~Hz}, \mathrm{H}-5), 3.65(1 \mathrm{H}, \mathrm{t}, J=10.2 \mathrm{~Hz}, \mathrm{H}-6), 3.82(1 \mathrm{H}$, 
$\mathrm{d}, J=9.5 \mathrm{~Hz}, \mathrm{H}-7$ ); ${ }^{13} \mathrm{C}-\mathrm{NMR}$ data, see Table 3 ; EIMS $m / z[\mathrm{M}]^{+} 336(18), 318(27), 300(15), 285(33), 278(22)$, $272(12), 260$ (17), 257 (21), 243 (17), 231 (28), 218 (16), 199 (12); HREIMS $m / z 336.2317\left[\mathrm{M}^{+}, \mathrm{C}_{20} \mathrm{H}_{32} \mathrm{O}_{4}\right.$ requires 336.2317 .

Triacetate (26); obtained by acetylation to $80^{\circ} \mathrm{C}$ for $12 \mathrm{~h}$; ${ }^{1} \mathrm{H}$ NMR $(200 \mathrm{MHz}) \delta 0.94,0.99,1.25$ (3H each, s), $1.10,(3 \mathrm{H}, \mathrm{d}, J=7 \mathrm{~Hz}, \mathrm{H}-17), 1.52(1 \mathrm{H}, \mathrm{d}, J=10 \mathrm{~Hz}$, H-5), 1.93, 2.01, 2.05 (3H each, s), 2.51 (1H, br s, H-13), 4.40 (1H, dd, $J=11,5 \mathrm{~Hz}, \mathrm{H}-3), 5.35(1 \mathrm{H}, \mathrm{d}, J=10 \mathrm{~Hz}$, $\mathrm{H}-7), 5.43(1 \mathrm{H}, \mathrm{t}, J=10 \mathrm{~Hz}, \mathrm{H}-6)$; ${ }^{1} \mathrm{H}$ NMR $(200 \mathrm{MHz}$, $\left.\mathrm{C}_{6} \mathrm{D}_{6}\right) \delta 0.83,1.03,1.06$ (3H each, s), $0.96(3 \mathrm{H}, \mathrm{d}, J=7$ $\mathrm{Hz}, \mathrm{H}-17), 1.13(1 \mathrm{H}, \mathrm{d}, J=10 \mathrm{~Hz}, \mathrm{H}-7), 1.67,1.73,1.76$ ( $3 \mathrm{H}$ each, s), $3.43(1 \mathrm{H}$, dd, $J=11,5 \mathrm{~Hz}, \mathrm{H}-3$ ), $5.54(1 \mathrm{H}$, $\mathrm{t}, J=10 \mathrm{~Hz}, \mathrm{H}-6), 5.68(1 \mathrm{H}, \mathrm{d}, J=10 \mathrm{~Hz}, \mathrm{H}-7)$; ${ }^{\mathrm{i}} \mathrm{C}-$ NMR data, see Table 3; EIMS $m / z\left[\mathrm{M}-\mathrm{HOAc}^{+} 402\right.$ (6), 360 (89), 342 (13), 327 (21), 300 (100), 285 (33), 257 (27), 231 (21), 203 (11); HREIMS $\mathrm{m} / \mathrm{z} 402.2413$ [M $\mathrm{HOAc}^{+}, \mathrm{C}_{24} \mathrm{H}_{34} \mathrm{O}_{5}$ requires 402.2406 .

$3 \alpha, 11 \beta, 16 \alpha-T r i h y d r o x y-15-0 x o-e n t-(16 S)$-kaurane (27): ${ }^{1} \mathrm{H}$ NMR $(200 \mathrm{MHz}) \delta 0.77,0.99,1.00,1.54$ (3H each, s), 2.24 (1H, br s, H-13), 3.25 ( $1 \mathrm{H}$, dd, $J=10$, $5 \mathrm{~Hz}, \mathrm{H}-3), 3.95(1 \mathrm{H}, \mathrm{d}, J=4.5 \mathrm{~Hz}, \mathrm{H}-11)$; ${ }^{13} \mathrm{C}-\mathrm{NMR}$ data, see Table 3; EIMS $m / z$ [M $\left.-\mathrm{H}_{2} \mathrm{O}\right]^{+} 318$ (2), 308 (4), 303 (2), 290 (19), 275 (15), 272 (12), 257 (34), 220 (27), 211 (5); HREIMS $m / z 318.2173\left\lfloor\mathrm{M}-\mathrm{H}_{2} \mathrm{O}\right]^{+}$, $\mathrm{C}_{20} \mathrm{H}_{30} \mathrm{O}_{3}$ requires 318.2195 .

3 $\alpha, 11 \beta$-Diacetaté (28): obtained by acetylation at room temperature; ${ }^{1} \mathrm{H}-\mathrm{NMR}(200 \mathrm{MHz}) \delta 0.85,0.89$, $1.07,1.45$ ( $3 \mathrm{H}$ each, s), $1.94,2.05$ (3H each, s), $2.30(1 \mathrm{H}$, br s, H-13), $4.46(1 \mathrm{H}$, dd, $J=11,5 \mathrm{~Hz}, \mathrm{H}-3), 5.05(1 \mathrm{H}$, d, $\left.\delta^{\prime}=4.5 \mathrm{~Hz}, \mathrm{H}-11\right)$; EIMS $m / z[\mathrm{M}]^{+} 420(1), 360(3)$, 332 (3), 317 (46), 300 (2), 289 (12), 285 (5), 272 (29), 257 (100), $229^{\circ}$ (72), 201 (20) HREIMS $m / z 420.2491[\mathrm{M}]^{+}$, $\mathrm{C}_{24} \mathrm{H}_{36} \mathrm{O}_{6}$ requires 420.2511 .

Triacetate (29); obtained as above warming at 80 ${ }^{\circ} \mathrm{C} ;{ }^{1} \mathrm{H}$ NMR $(200 \mathrm{MHz}) \delta 0.85,0.89,1.05,1.69$ (3H each, s), $1.94,2.00,2.05(3 \mathrm{H}$ each, s), $4.46(1 \mathrm{H}, \mathrm{dd}, J=11,5$ $\mathrm{Hz}, \mathrm{H}-3), 5.04(1 \mathrm{H}, \mathrm{d}, J=5 \mathrm{~Hz}, \mathrm{H}-11) ;{ }^{3} \mathrm{C}-\mathrm{NMR}$ data, see Table 3; EIMS $m / z 402$ (M - HOAc ${ }^{+}$(2), 377 (5), 360 (72), 342 (82), $332(15), 317(10), 300(40), 299(5)$, 282 (21), 267 (44), $257(85), 229$ (90), 211 (16). HREIMS $m / z 402.2399$ [M - $\mathrm{HOAc}^{+}, \mathrm{C}_{24} \mathrm{H}_{34} \mathrm{O}_{5}$ requires 402.2406 .

Acknowledgment. We thank the DGICYT, Ministry of Education and Science, Spain, for financial support, and Prof. M. Grande, University of Salamanca, for a generous sample of 2.

\section{References and Notes}

(1) Fraga, B. M.; González, P.; Hernández, M. G.; Tellado, F. G.; Perales, A. Phytochemistry 1986, 25, 1235.1237.

(2) Fraga, B. M.; Hernández, M. G.; González, P. Phytochemistry $1992,31,3845-3849$.

(3) MacMillan, J. Hormonal Regutation of Development. Molecular Aspects of Plant Hormones, Springer Verlatg: Berlin 1980.

(4) Fraga, B. M.; Hanson, J. R.; Hernández, M. G.; Sarah, F. Y. Phytochemistry 1980, 19, 1087-1091.

(5) Bearder, w. R.; Dennis, F. G.; MacMillan, J.; Martin, G. C.; Phinney, B. O. Tetrahedron Lett. 1975, 669-670.

(6) Wada, K.; Imai, T.; Yamashita, H. Asric. Biol. Chem, 1881, 45, $1833-1842$

(7) Fraga, B. M.; Gonzalez, A. G.; Hanson, J. R.; Hernández, M. Phytochemistry 1981, 20, 57-61.

(8) Nagashimz, F.; Toyota, M.; Asakawa, Y. Phytochemistry 1990, 29. $2169-2174$.

(9) Grande. M.; Segura, M.; Mancheňo, B. J. Nat. Prod. 1986, 49, $259-264$.

(10) Grande, M.; Macías, M. J.; Mancheño, B.; Segura, M.: Zarzo, A. J.Nat. Prod. $1991,54,866-869$.

(11) Dennis, D. T.; Upper, C. D.; West, C. A. Plant Physiol. 1965, 40,948-952.

(12) Cross, B. E.; Myers, P. L. Phytochemistry 1969, 8, 79-83.

(13) Barnes, M. F.: MacMillan, J. J. Chem. Soc, C 1967. 36I-366.

(14) Nagashima, F.; Tanaka, H.; Takanka, S.; Asakawa, Y. Phytochemistry 1996, $41,1129-1141$.

(15) Boaventura, M. A.; Hanson, J. R.; Hitcheock, P. B.; Takahashi, J. A. Phytochemistry 1994, $37,387-389$

(16) Fraga, B. M.; Gunzález, P.; Guillermo, R.; Hernández, M. G.; Perales, A. Tetrahedron 1995, 5I, $10053-10064$.

(17) Wu, C.; Shen; W.; Wang, Z; Cheng, P. Fenxi Ceshi Tonghoo 1992 , 11, 79--83; Chem. Abstr. 1994, 120, 294083n.

(18) Takeda, Y.; Ichihara, T.; Yamasaki, K.; Otsuka, H.; Utsumi, H. Phytechemistry 1993, 32, 145-150.

(19) Hanson, J. R. Hawker, J; White, A. F. J. Chem. Soc., Perkin Trans. 7 1972, $1892-1895$.

NP960405Q 